\title{
Retrospective seroepidemiological analysis of patients with suspicion of paracoccidioidomycosis in São Paulo State, Brazil
}

\author{
Kamikawa CM (1, 2), Kohara VS (1), Passos AN (1, 2), Vicentini AP (1, 2)
}

(1) Laboratory of Mycosis Immunodiagnosis, Center of Immunology, Adolfo Lutz Institute, São Paulo, São Paulo State, Brazil; (2) Postgraduate Program in Sciences, Disease Control Coordination, State Secretariat of Health of São Paulo, São Paulo, São Paulo State, Brazil.

\begin{abstract}
The geographic distribution of paracoccidioidomycosis (PCM) in the Brazilian state of São Paulo was evaluated in a retrospective study using secondary data from serological analyses, carried out by double immunodiffusion assay of patients with PCM suspicion, from January 1999 to May 2010. Sixty percent of 10,176 patients, from 239 cities, were serologically reactive to $P$. brasiliensis. The cities that showed the most serological reactivity among patients were São João da Boa Vista (85\%), Piracicaba (75\%), Sorocaba (73\%), Campinas (72\%) and São Paulo (62\%). São Paulo state has an area of $248,209.4 \mathrm{~km}^{2}$; the climate is tropical and sub-tropical with annual temperatures between 18 and $24^{\circ} \mathrm{C}$, high rainfall ( 900 to $1800 \mathrm{~mm} /$ year), rainy summers and mild winters. It also features large areas composed of acidic soils, and is one of the greatest contributors to Brazilian agricultural production and, separately, the largest producer of orange juice and, the ninth greatest producer of soy and sugar cane and the fourth largest coffee producer. We suggest that the climatic characteristics associated with soil type and development of primary activities can contribute to the endemic potential of PCM in São Paulo state.
\end{abstract}

Key words: Paracoccidioides brasiliensis, paracoccidioidomycosis, immunological tests, seroepidemiological studies.

\section{INTRODUCTION}

Described for the first time more than a century ago by Adolpho Lutz, paracoccidioidomycosis (PCM) is the systemic mycosis of greatest impact on Latin America, with approximately 10 million people infected in endemic areas (1). It is known that the etiologic agent belongs to the Paracoccidioides genus, whose species, formerly known as $P$. brasiliensis, constitute the point of discussions, since molecular studies had demonstrated the occurrence of speciation culminating with the classification of P. brasiliensis into three cryptic species: S1 (found in Brazil, Argentina, Paraguay, Peru, and Venezuela), PS2 (Brazil and Venezuela) and PS3 (Colombia) (1, 2). More recently, a new species, $P$. lutzii, has been isolated in the midwest region of Brazil and Venezuela $(1,3)$.

P. brasiliensis presents a long period of latency whereas human infection occurs mainly by inhalation of conidia present in soil, water and plant harvests. The infection is usually acquired during the first two decades of life (incidence peaks between 10 and 20 years old); clinical manifestations are uncommon in this age range and generally occur in a small percentage of individuals by reactivation of a latent infection $(1,4)$. Many studies have established that PCM is more prevalent among rural workers engaged in intensive agricultural activities, particularly on coffee, cotton, and tobacco plantations (5-7).

In Brazil, PCM has a high endemicity and contributes to $80 \%$ of all cases reported in Latin 
America. It is important to emphasize that the highest number of cases had been diagnosed clinically or in the laboratory in the southern, southeastern and central west of the country. Epidemiological studies estimate that the disease incidence is 3 to 4 new cases/million inhabitants per year with a mortality rate of 0.14 per 100,000 inhabitants (7). Recent data obtained from the Ministry of Health in 2011 (8) show an annual average of 160 deaths due to paracoccidioidomycosis in Brazil, higher than any other important mycoses such as cryptococcosis, candidiasis, aspergillosis etc.

The importance of PCM for public health is closely related to the existence of extensive endemic areas, the frequent involvement of individuals in the most productive period of life, the possibility of being considered an occupational disease, the long time required for treatment, the high rate of relapse, mainly due to failures and noncompliance, and the important sequelae that are debilitating to most patients. All these conditions determine a significant and high socioeconomic cost to the state, and for most researchers are also considered a serious public health problem $(1,5,79,10)$. Unfortunately, in Brazil, PCM is not considered a compulsorily notifiable disease, which has greatly impaired the assessment of the true prevalence and incidence of this mycosis in the country, hindering the adoption of control and/or prevention measures $(7,11,12)$. However, in such Brazilian states as Minas Gerais, Mato Grosso do Sul and Rondonia, the affliction is already considered a disease of compulsory notification, and in São Paulo, since 2009 it has been recommended that all confirmed cases of the disease be reported to the Health Department (12).

Given the aforementioned context, the main objective of this work was to evaluate the geographical distribution of paracoccidioidomycosis in the state of São Paulo through a retrospective study using secondary data obtained from a routine of serological analysis of patients with clinical suspicion of mycosis sent to the Laboratory of Mycosis Immunodiagnosis, Center of Immunology, Adolfo Lutz Institute, São Paulo, from January 1999 to May 2010.

\section{PATIENTS AND METHODS}

We analyzed retrospectively, data of serological diagnoses from 10,176 patients with clinical suspicion of paracoccidioidomycosis, sent to the Laboratory of Mycosis Immunodiagnosis, Center of Immunology, Adolfo Lutz Institute from January 199 to May 2010, for the presumptive and/or confirmatory diagnosis, carried out by double immunodiffusion (DI) assay against $P$. brasiliensis culture filtrate antigen. The following patient information: the presence or absence of anti-Paracoccidioides brasiliensis antibodies, origin, sex/gender and age were obtained from a database (Microsoft Access 2000) of the Laboratory of Mycosis Immunodiagnosis.

All requests for serological analysis of paracoccidioidomycosis were classified according to the guidelines of the administrative division of the State Secretariat of Health of São Paulo, through the Regional Department of Health (DRS), published in the Official Gazette of the State of São Paulo, decree n. 51433 of December $28^{\text {th }}, 2006$. According to this decree, the state of São Paulo was divided into 17 DRS, which are responsible for coordinating activities at the regional level and promoting the inter-sector coordination with municipalities and civil society organizations (13). São Paulo state has 645 municipalities while, according to the Brazilian Institute of Geography and Statistics (IBGE) (14), its population in 2010 was $41,262,199$ inhabitants in a land area of $248,196.960 \mathrm{~km}^{2}$.

\section{Double Immunodifusion Assay (DI assay)}

Reactions were performed according to the modified method of Ouchterlony (15). Briefly, glass slides were covered with $3.0 \mathrm{~mL}$ of a gel composed of $1 \%$ agarose type II medium (Sigma Chemical Co., USA) in buffered saline ( $\mathrm{pH}$ 6.9) containing $0.4 \%$ sodium citrate and $7.5 \%$ glycine. Antigen $(12 \mu \mathrm{L})$ was placed in the central well, whereas reference and patients' sera $(12 \mu \mathrm{L})$ were loaded into the surrounding wells. The slides were incubated in a humid chamber at room temperature for 48 hours. They were then washed in saline with several changes over a 24-hour period. The gels were dried and stained with $0.4 \%$ Coomassie Brilliant Blue R-250 (Sigma Chemical Co., USA) in a solvent composed of a mixture of ethanol, acetic acid and water.

\section{Paracoccidioides brasiliensis Antigens}

The antigen used was a 20-day culture filtrate (Ag CF) obtained, according to Garcia et al. (16) 
with some modification, from the yeast phase of $P$. brasiliensis (strain B-339) (17). The fungus was cultured in NGTA liquid medium for 20 days at $36^{\circ} \mathrm{C}$ with shaking. After incubation time, the culture was treated with borate-thimerosal solution $(1: 5,000)$, filtered, aliquoted and stored at $4^{\circ} \mathrm{C}$ until use.

\section{RESULTS}

The DI assay revealed the presence of anti-P. brasiliensis antibodies in $15.6 \%(1,589)$ of the serum samples evaluated. Among those samples reactive to Paracoccidioides brasiliensis, 89\% were from males and $11 \%$ from females, thereby showing a male-to-female ratio of $8: 1$. The age distribution ranged between 41 to 60 years in both genders.

Throughout the study period, 10,949 tests for presumptive and/or confirmatory diagnosis of PCM were requested to the Laboratory of Mycosis Immunodiagnosis. Analysis of data recorded from 1999 to 2006 had shown an increasing number of tests requested year by year, with the exception of a slight decrease in 2007; a trend in reducing the number and/or percentage of patients presenting reactivity to PCM did not occur (Figure 1).

Of the 645 cities of São Paulo state, 239 (37\%) sent requests to conduct a survey of anti- $P$. brasiliensis antibodies. The Campinas Regional Department of Health (Campinas DRS) presented the greatest number of cities that requested the DI assay $(n=33)$, followed by Sorocaba $(n=30)$ and São Paulo (the state capital), with 29 cities (Figure 2 and Table 1). The DRS with the fewest requests were Araraquara and Franca with two and three cities requesting, respectively.

Among all DRS, the cities with higher serological reactivity to $P$. brasiliensis among patients were: São João da Boa Vista with $85 \%$ (12/14), Piracicaba 75\% (12/16); Sorocaba 73\% (22/30), Campinas 72\% (24/33) and São Paulo City $62 \%(18 / 29)$. It is important to note that the Franca DRS had the same number of municipalities requesting tests and with reactive patients, only three (Figure 3).

\section{DISCUSSION}

The analysis of secondary data extracted from the database of the Laboratory of Mycosis Immunodiagnosis proved to be extremely important for demonstrating the breadth of paracoccidioidomycosis in the state of São Paulo.

The analysis of information from the 10,176 patients showed that $15.6 \%(1,589)$ of individuals presented anti- $P$. brasiliensis antibodies. Out of these, $88.9 \%$ (1413) patients were male and

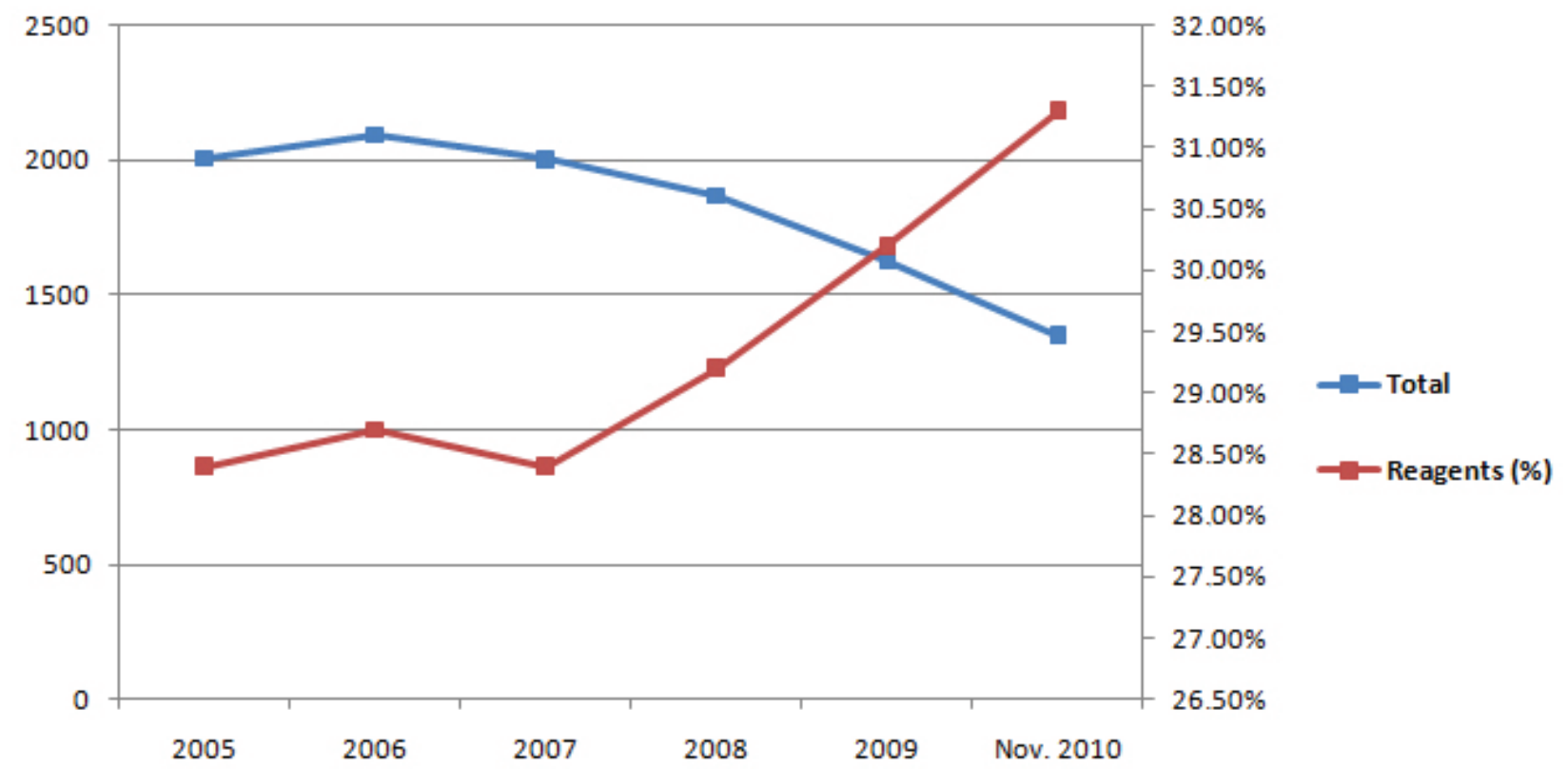

Figure 1. Comparison between absolute sample numbers and percentage of samples reactive to $P$. brasiliensis received for analysis by the Laboratory of Mycosis Immunodiagnosis from January 1999 to May 2010. 


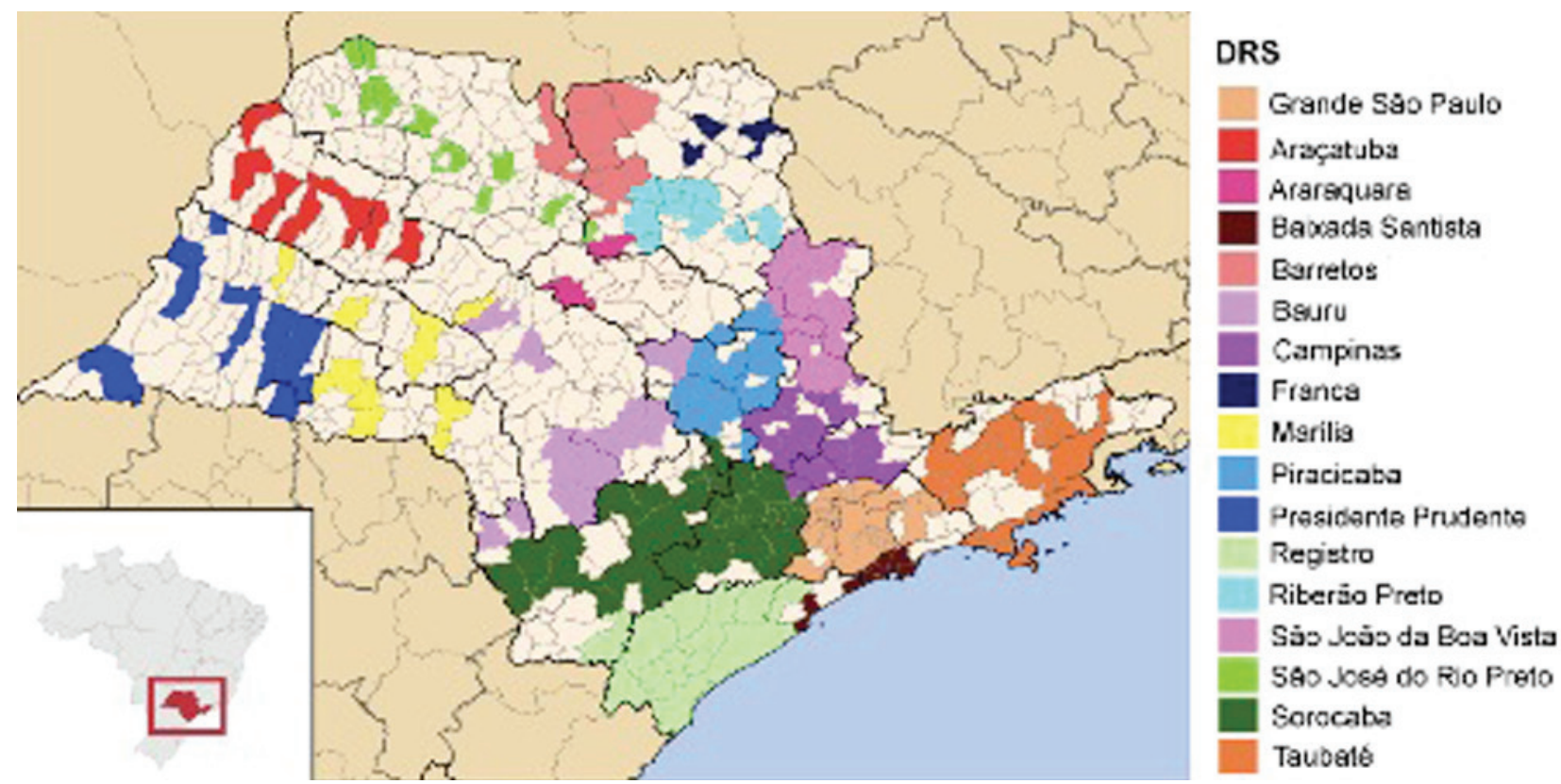

Figure 2. Geographical distribution of municipalities, according to Regional Department of Health (DRS), that requested immunodiffusion assay for paracoccidioidomycosis from January 1999 to May 2010.
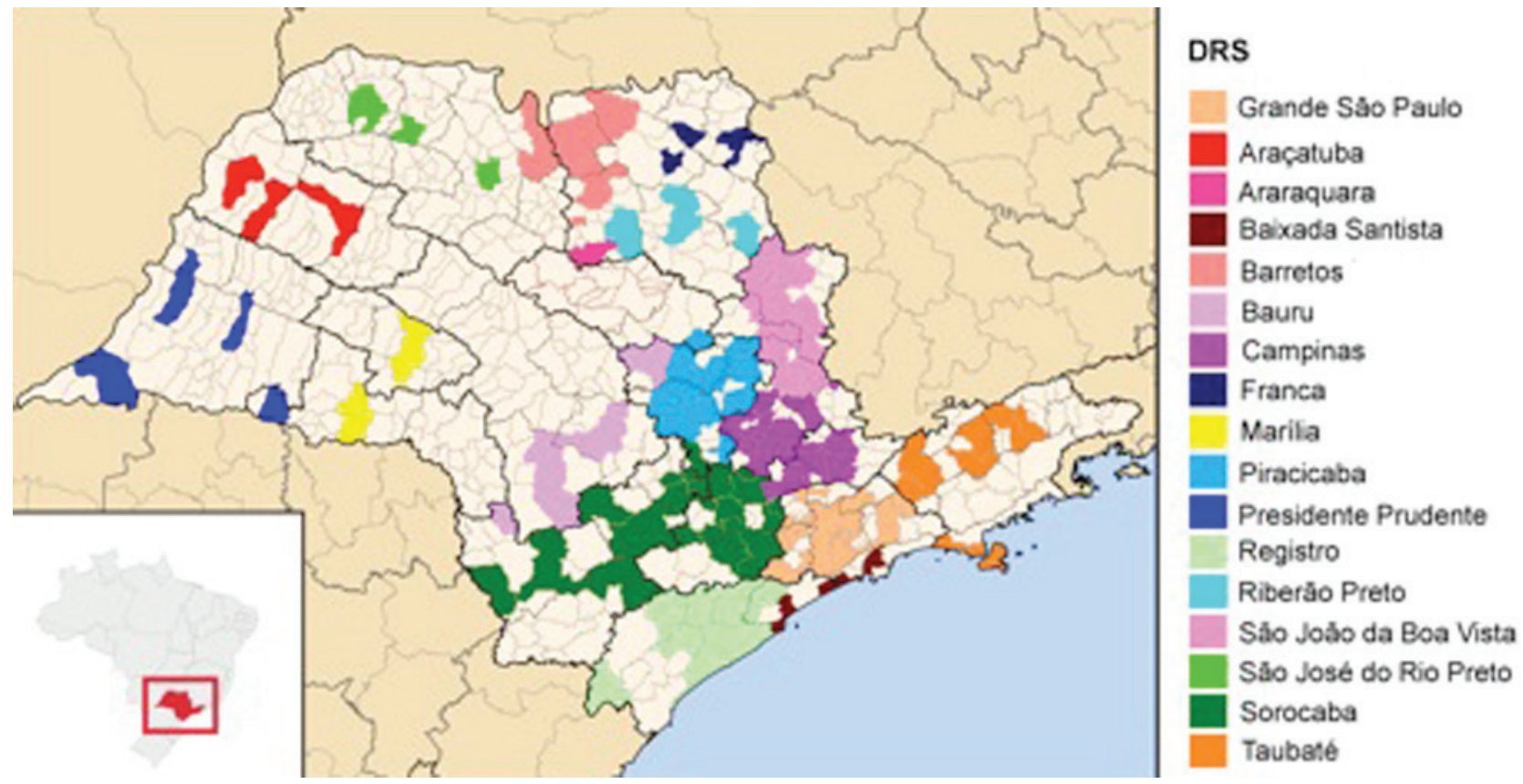

Figure 3. Geographical location of 143 municipalites, according to Regional Department of Health (DRS), with anti-P. brasiliensis antibody detection from January 1999 to May 2010.

$11.1 \%$ (176) female, showing an 8:1 ratio in favor of males, confirming the data in the literature. Moreto (18) described a gender ratio of 7.2:1 versus 5.4:1 reported by Blotta et al. (5). Marques et al. (10), in an epidemiological study of patients in the city of Botucatu, observed a male-to-female ratio of 10.7:1. In Curitiba, Paraná state, TellesFilho et al. (19) demonstrated a 9.1:1 gender ratio compared with 10.2:1 found by Almeida et al. (20).

It is noteworthy that cases of $P$. brasiliensis infection described in females are often observed when these patients are in the prepubertal, menopausal and/or have undergone hysterectomy, conditions that result in the absence of the hormone $\beta$-estradiol (21). 
Table 1. Distribution of requests for paracoccidioidomycosis immunodiffusion assay by Regional Department of Health (DRS) from January 1999 to May 2010

\begin{tabular}{c|c|c|c|c|c}
\hline \multirow{2}{*}{ Regional Department of Health } & \multicolumn{2}{|c|}{ Reactive } & \multicolumn{2}{c|}{ Non-reactive } & \multirow{2}{*}{ Total } \\
\cline { 2 - 5 } & Male & Female & Male & Female & \\
\hline Capital & 336 & 29 & 1833 & 889 & 3087 \\
\hline Araçatuba & 22 & 0 & 49 & 13 & 84 \\
\hline Araraquara & 4 & 0 & 17 & 15 & 36 \\
\hline Baixada Santista & 13 & 0 & 38 & 10 & 61 \\
\hline Barretos & 52 & 5 & 160 & 50 & 267 \\
\hline Bauru & 20 & 1 & 83 & 41 & 145 \\
\hline Campinas & 360 & 55 & 1240 & 583 & 2238 \\
\hline Franca & 6 & 0 & 14 & 0 & 20 \\
\hline Marília & 6 & 1 & 23 & 6 & 36 \\
\hline Piracicaba & 90 & 10 & 158 & 74 & 332 \\
\hline Presidente Prudente & 15 & 0 & 37 & 5 & 57 \\
\hline Registro & 18 & 3 & 297 & 187 & 505 \\
\hline Ribeirão Preto & 12 & 4 & 149 & 64 & 229 \\
\hline São João da Boa Vista & 149 & 20 & 348 & 151 & 668 \\
\hline São José do Rio Preto & 70 & 4 & 283 & 117 & 474 \\
\hline Sorocaba & 181 & 38 & 718 & 370 & 1307 \\
\hline Taubaté & 48 & 5 & 297 & 93 & 443 \\
\hline Origin unknown & 11 & 1 & 95 & 80 & 187 \\
\hline Total & 1413 & 176 & 5839 & 2748 & 10176 \\
\hline & & & 53 & 23 \\
\hline
\end{tabular}

The prevalence of the 41 to 60-year-old age range among these patients did not differ significantly between the genders. Importantly, there are no other studies available that have applied the same analysis performed in this study. The few existing studies assessing the age of the patients were based on the cellular immune response evaluation (reaction of delayed-type hypersensitivity), serological evaluation using different antigens or method in patients classified according to the clinical form of the disease, i.e., acute PCM/juvenile and chronic PCM/adults, or by mortality studies. In addition, we observed that the proportion of test requests that did not provide the patient's age information of was significant: $11.5 \%(1,177)$.

Among the 645 cities of São Paulo, 239 had sent samples for analysis, of which 143 (59.8\%) had at least one patient with circulating anti-P. brasiliensis antibodies. The macro-regions in focus with the highest reactivity proportions among patients were São João da Boa Vista (85\%), Piracicaba (75\%), Sorocaba (73\%) and Campinas (72\%). In a study of PCM-related mortality in São Paulo state, Santo (22) showed coefficients of 8.73 in Botucatu, 7.74 in São João da Boa Vista and 7.25 in Barretos, according to death certificates from 1985 to 2005, which indicated PCM as the cause of death in the first line or in any part of the document.

The evaluation of the primary activities in these regions showed that the cultivation of sugarcane, coffee and orange are dominant. In addition, the fact that Paracoccidioides spp. 
preferentially inhabits the soil, would suggest that soil management disperses aerosols in the area. Therefore, individuals who work in these activities who exhibit depressed immunity or who undergo repetitive exposure to the pathogen, actually become more susceptible to infection.

Importantly, the original vegetation that covered approximately $80 \%$ of São Paulo state in the year of 1854 was nearly devastated by the creation of farmland, pasture and/or the extraction of wood for fuel or raw material. From 1920 onward, such devastation began to coincide geographically with the macro-region of cities with the highest rates of patients reactive to PCM. Today, native forests occupy less than $3 \%$ of the state in areas unsuitable for crops or pasture and not yet incorporated into the agricultural economy $(14,23)$.

The percentage of samples that reacted to Paracoccidioides brasiliensis sent to the Laboratory of Mycosis Immunodiagnosis (15.6\%) does not represent the statewide reactivity rate for all of São Paulo, since numerous individuals with clinical suspicion of PCM and/or with active and/ or monitoring disease, are diagnosed by other services, particularly universities and teaching hospitals such as those in Botucatu, Campinas, Ribeirão Preto as well as others connected to university dentistry training programs like Araraquara, Bauru, etc. In São Paulo, the Federal University of São Paulo Hospital and the Laboratory of Mycoserology of the Institute of Tropical Medicine of the University of São Paulo (USP) are also units that perform the diagnosis of individuals with clinical suspicion of these mycoses. It becomes imperative to note that more precise and/or reliable information would be obtained if we could combine the records from all the health services in São Paulo state responsible for the laboratory diagnosis of paracoccidioidomycosis, whether accomplished through mycological assessement including direct examination, isolation and culture, histopathological analysis or by detection of antibodies and/or antigens by immunological assays.

Additionally, the low reactivity percentage found in the present study compared to other serological studies could be explained by several factors:

- the fact that the double immunodiffusion reaction acts as serological screening, thus sometimes preventing the proper detection of species-specific antibodies, mainly in patients with similar clinical manifestations, especially pulmonary ones, as observed in tuberculosis;

- "early" sample collections, prior to biological production of anti-P. brasiliensis antibodies by the immune system;

- absence of seroconversion;

- low concentration of anti-P. brasiliensis antibodies, below the detection limit of the DI assay;

- patient infected with a strain of Paracoccidioides brasiliensis whose antigenic constitution is different from that used in the diagnostic test;

- low avidity of IgG2, directed to epitopes consisting of carbohydrates.

One should also bear in mind that in many instances the absence of immune response may be related to the clinical form of disease. In cases of more severe PCM it is very common that the excess of antigen in the patient's body forms immune complexes with pre-existing antibodies. In this case, it is suggested that after a period of treatment, the amount of antigen will decrease, and antibody will be released and subsequently react positively. The information available in the literature are mainly based on epidemiological surveys and the experience of referral services in encountering patients with the disease, which hampers the differentiation and comparison of our results with others $(24,25)$.

Among the Brazilian states, São Paulo is one of the greatest contributors to agricultural production. The climatic and physiographic features found in the state, combined with the scarce information regarding the prevalence of paracoccidioidomycosis, clearly demonstrate that this is an area endemic for fungal infections.

The present work highlights the difficulties and challenges facing the scientific community as to epidemiological studies of $P$. brasiliensis as a possible new species. Rather than discouraging us from this line of study, these difficulties encourage us to proceed with greater zeal and dedication to achieve new discoveries and knowledge.

\section{ACKNOWLEDGMENTS}

We gratefully acknowledged the grant of a fellowship by the Professional Enhancement Program of the State Secretariat of Health of São Paulo to C. M. Kamikawa (2009-2011). We also 
thank Marisa Ailin Hong for her help in revising the manuscript.

\section{COPYRIGHT}

(c) CEVAP 2012

\section{SUBMISSION STATUS}

Received: January 9, 2012.

Accepted: March 29, 2012.

Abstract published online: April 5, 2012.

Full paper published online: August 31, 2012.

\section{CONFLICTS OF INTEREST}

The authors declare no conflicts of interest.

\section{FINANCIAL SOURCE}

Adolfo Lutz Institute (project CTC-CEPIALIAL\#107/07) and the Disease Control Coordination of the State Secretariat of Health of São Paulo provided the financial grants.

\section{ETHICS COMMITEE APPROVAL}

The present study was approved by the Ethics Committee of the Adolfo Lutz Institute (protocol number 107/97).

\section{CORRESPONDENCE TO}

Adriana Pardini Vicentini, Laboratório de Imunodiagnóstico das Micoses, Centro de Imunologia, Instituto Adolfo Lutz, Av. Dr. Arnaldo, 351, $11^{\circ}$ andar, sala 1104, São Paulo, SP, 01246-902, Brasil. Phone: +55 113068 2900. Fax: +55113068 2898. Email: apardini@ial.sp.gov.br.

\section{REFERENCES}

1. Colombo AL, Tobón A, Restrepo A, Queiroz-Telles F, Nucci M. Epidemiology of endemic systemic fungal infections in Latin America. Med Mycol. 2011;49(8):785-98.

2. Matute DR, McEwen JG, Montes BA, San-Blas G, Bagagli E, Rauscher JT, et al. Cryptic speciation and recombination in the fungus Paracoccidioides brasiliensis as revealed by gene genealogies. Mol Biol Evol. 2006;23(1):65-73.

3. Teixeira MM, Theodoro RC, de Carvalho MJ, Fernandes L, Paes H, Hahn RC, et al. Phylogenetic analysis reveals a high level of speciation in the Paracoccidioides genus. Mol Phylogenet Evol. 2009;52(2):273-83.

4. Ferreira MS. Paracoccidioidomycosis. Paediatr Respir Rev. 2009;10(4):161-5.

5. Blotta H, Mamoni RL, Oliveira SJ, Nouér SA, Papaiordanou PM, Goveia A, et al. Endemic regions of paracoccidioidomycosis in Brazil: a clinical and epidemiologic study of 584 cases in the southeast region. Am J Trop Med. 1999;61(3):390-4.

6. Calle D, Rosero DS, Orozco LC, Camargo D, Castañeda E, Restrepo A. Paracoccidioidomycosis in Colombia: an ecological study. Epidemiol lnfect. 2001;126(2):309-15.

7. Silva-Vergara ML, Martinez R, Chadu A, Madeira M, Freitas-Silva G, Leite Maffei CM. Isolation of Paracoccidioides brasiliensis strain from the soil of a coffee plantation in Ibiá, State of Minas Gerais, Brazil. Med Mycol. 1998;36(1):37-42.

8. Coutinho ZF, Silva D, Lazera M, Petri V, Oliveira RM, Sabroza PC, et al. Paracoccidioidomycosis mortality in Brazil (1980-1995). Cad Saúde Pública. 2002;18(5):1441-54.

9. Ministério da Saúde. DATASUS. Sistemas e Aplicativos TabWin. [accessed in 2011 Apr 22]. Available from: http://www2.datasus.gov.br/DATASUS/index. php?area $=040805$.

10. Marques SA, Franco MF, Mendes RP, Silva NC, Baccilli C, Curcelli ED, et al. Aspectos epidemiológicos da paracoccidioidomicose na área endêmica de Botucatu (São Paulo - Brasil). Rev Inst Med Trop São Paulo. 1983;25(2):87-92.

11. BRASIL. Resolução SES n. 1.481, de 16 de maio de 2008. Acrescenta agravos estaduais a Lista Nacional de Doenças de Notificação Compulsória e dá outras providências. Secretaria de Estado de Saúde de Minas Gerais, Minas Gerais, MG, 16 mai. 2008.

12. Mendes RP. Paracoccidioidomycosis surveillance and control. J Venom Anim Toxins incl Trop Dis. 2010;16(2):194-7.

13. Governo do Estado de São Paulo. Secretaria da Saúde; [accessed in $2010 \mathrm{Jul}$ 26]. Available from: http://www. saude.sp.gov.br.

14. Instituto Brasileiro de Geografia e Estatística. Estados; [accessed in 2010 Ago 10]. Available from: http:// www.ibge.gov.br/estadosat/.

15. Ouchterlony O. Antigen-antibody reactions in gels. Acta Pathol Microbiol Scand. 1949;26(4):507-15.

16. Garcia NM, Assis CM, Del Negro GMB, Aguiar MSMV, Lacaz CS. Análise imunoquímica de antígeno metabólico de P. brasiliensis. Rev Inst Med Trop São Paulo. 1993;35(Suppl.10):70.

17. Silva DF. Análise da estabilidade de exoantígenos de Paracoccidioides brasiliensis [Dissertação]. São Paulo: Coordenadoria de Controle de Doenças - Secretaria de Estado da Saúde de São Paulo; 2005.

18. Moreto TC. Diagnóstico da paracoccidioidomicose em pacientes atendidos em serviços de rotina de hospital universitário [Dissertação]. Botucatu: Universidade Estadual Paulista, Botucatu; 2010.

19. Telles-Filho FQ, Brandão HE, Macedo E, Barros JA, Marquetti JL, Purim KS, et al. Alguns aspetos clínicos e epidemiológicos da paracoccidioidomicose no Estado do Paraná. Rev Soc Bras Med Trop 1986;19(Supl 1):93.

20. Almeida F, Lacaz CS, Cunha AA. Dados estatísticos sobre a granulomatose paracoccidióica (blastomicose sul-americana ou paracoccidioidomicose). Rev Bras Med. 1946;3(2):91-4.

21. Shankar J, Restrepo A, Clemons KV, Stevens 
DA. Hormones and the resistance of women to paracoccidioidomycosis. Clin Microbliol Rev. 2011;24(2):296-313.

22. Santo $\mathrm{AH}$. Tendência da mortalidade relacionada à paracoccidioidomicose, Estado de São Paulo, Brasil, 1985 a 2005: estudo usando causas múltiplas de morte. Rev Panam Salud Publica. 2008;23(5):313-24.

23. Governo do Estado de São Paulo. Levantamento Censitário das Unidades de Produção Agropecuária do Estado de São Paulo; [accessed in 2011 Apr 18]. Available from: http://www.cati.sp.gov.br/projetolupa/ mapaculturas.php.
24. Rodrigues CC. Avaliação da infecção por Histoplasma capsulatum por meio de reações intradérmicas em moradores da zona urbana e rural do município de Pratânia (SP) [Dissertação]. Botucatu: Universidade Estadual Paulista - Faculdade de Medicina de Botucatu; 2004.

25. Fornajeiro N, Maluf ML, Takahachi G, Svidzinski TI. Inquérito epidemiológico sobre a paracoccidioidomicose utilizando a gp43 em dois municípios do noroeste do Paraná, Brasil. Rev Soc Bras Med Trop. 2005;38(2):191-3. 